\title{
Postmoderne kerk-wees in die lig van publieke teologie - eenheid en verskeidenheid
}

\author{
Yolanda Dreyer \\ Departement Praktiese Teologie \\ Universiteit van Pretoria
}

\begin{abstract}
Being postmodern church in light of public theology

- unity and diversity

Foundationalism criticizes the "relativism" of postmodernity which deconstructs absolute and objective totalitarian truth claims. Although most postmodern scholars deny advocating relativism, they do acknowledge that plurality features significantly in postmodern thinking. Plurality and diversity are important to the theological discourse tool, because the church claims to be catholic and ecumenical. In a postmodern context people who do not necessarily affiliate with the institutional church may nevertheless regard themselves as Christians. The article supports a public theological discourse and aims to provide a framework for reflection on unity and diversity in postmodern faith communities. Public practical theology includes the public as one of its audiences. After a brief overview of the phenomenon of postmodernity, the article explores the role of plurality in ecclesiology. It reflects on the challenge of facilitating a dialogue between members of churches and those who regard themselves as spiritual in the secularized context of a "churchless Christianity". The purpose of the article is to contribute to the ecumenism and the catholicity of the church.
\end{abstract}

\section{INLEIDING}

Toe mense van dieselfde volk en kultuur wat dieselfde taal gepraat het op plase en in klein dorpies geleef het, redelik geïsoleerd van wat in die res van die wêreld gebeur, en Sondae na dieselfde kerk toe gegaan het, het hulle redelik eners gedink en geglo. Vandag is dit anders. Mense op plase sien op TV wat in die res van die wêreld gebeur. Deur middel van die internet het hulle toegang tot (letterlik) "al die kennis in die wêreld". In dorpe en stede woon en werk deesdae mense van verskillende kulture wat verskillende tale praat. Binne dieselfde kultuur verskil denke en sienswyses, soms radikaal. 


\section{Postmoderne kerk-wees in die lig van publieke teologie}

Mense in dieselfde kerk benader die Bybel verskillend, glo nie presies dieselfde nie, en beoefen hulle spiritualiteit op 'n verskeidenheid maniere.

In die hedendaagse wêreld en kerk is daar mense wat gemaklik voel in die denkpatrone van die moderne wêreld, daar is steeds sekere premoderne sienings in omloop, en daar is mense wat aanklank vind by die postmoderne kritiek op moderne denke. Verskillende Skrifbeskouings, interpretasies en geloofspraktyke kan lei tot spanning en misverstande wat die eenheid van die kerk in gevaar stel. Hoe kan 'n kerk wat self nie raad weet nie, oortuigend kerk wees in die wêreld?

In 'n poging om die ongemak wat verskille oproep, uit die weg te ruim, keer sommige mense terug na konserwatiewe denke en selfs fundamentalisme, wat veld wen in menige kerklike kringe. Die verskynsel is al "foundationalism" (fondamentalisme) genoem (kyk Guardino 1989:241-252; 1990:221-235; 1995-96:57-69). Postmoderne denke dekonstrueer modernisme se beklemtoning van sogenaamde absolute en totalitêre "objektiewe" waarheidsaansprake. Volgens die kritici is "relativisme" die konsekwensie. Die meeste postmoderne teoloë pleit onskuldig op die aanklag van relativisme. Hulle erken egter wel dat die konsep "pluraliteit" 'n belangrike rol speel in die postmoderne konteks. Tradisioneel was pluraliteit nog altyd ter sprake waar die kerk bely dat dit katoliek ("algemeen") en één is. Die verskynsel van pluraliteit in die hedendaagse "wêrelddorp" vra teologiese refleksie oor hoe om nuwe betekenis te gee aan die ou belydenis binne die veranderde konteks.

Die vertrekpunt vir die teologiese diskoers in hierdie artikel word gevind in die "publieke praktiese teologie". Een van die aannames is byvoorbeeld dat dit moontlik is om 'n Christen te wees sonder om formeel lidmaat van die kerk te wees. Publieke teologie erken dat spiritualiteit buite die gevestigde kerk bestaan (kyk o a Palmer 1981; Oswald \& Leas 1987; Huber 1998). Hierdie vertrekpunt voorsien 'n raamwerk om binne 'n postmoderne kerk oor eenheid en verskeidenheid na te dink. Die doel van die artikel is om te fokus op die rol wat die begrip "pluraliteit" speel binne die verskynsel postmoderniteit. Die bevindings van hierdie bespreking word toegepas op die ekklesiologie en relevant gemaak vir eenheid van en diversiteit in postmoderne geloofsgemeenskappe. Moontlikhede vir 'n gesprek met spirituele mense in 'n gesekulariseerde konteks word ondersoek, sodat die ekumene en die katolisiteit van die kerk in die postmoderne wêreld gedien kan word.

\section{DIE "PROBLEEM VAN RELATIWISME"}

Christene se kritiek op die postmoderne verwerping van "absolute waarheid" is dikwels dat dit relativisme inhou. Die vrees is dat, as die geloof nie op 
absolute waarheid gebou is nie, daar eintlik niks meer oor is om in te glo nie. Brian McLaren ([1998] 2000:166-167) open egter 'n meer positiewe perspektief. Die postmoderne beswaar is volgens hom nie teen "absolute waarheid" daar buite nie (byvoorbeeld in Christelike taal dat God die absolute is). Dit is teen die arrogante idee dat mense met hulle beperkte verstand en insigte daardie absolute waarheid volledig kan ken. Binne die Christelike geloof sou dit beteken dat mense nie in staat is om die absolute waarheid (God) te kan omvat en artikuleer sodat ander dit akkuraat sal kan verstaan nie. Die postmoderne beswaar harmonieer dus met die Bybelse idee dat mense in hierdie aardse bedeling maar ten dele ken (1 Kor 13:12b).

Nogtans is daar baie gelowiges wat "die absolute waarheid" wil verdedig. As hulle wat nie die waarheid kan ken, verwoord en kommunikeer nie, ander van "die absolute waarheid" wil oortuig, wat is hulle eintlik besig om te doen? Volgens McLaren (2000:166) beskerm hulle daarmee nie die Bybelse geloof (wat self bevestig dat mense net ten dele ken) nie. Hulle beskerm moderne rasionalisme, wat selfversekerd is oor die menslike vermoë tot absolute kennis (wat dus teen die Bybel ingaan). Wanneer mense wat die Absolute nie absoluut kan ken nie, nogtans meen dat hulle verstaan van God en die Bybel gelyk is aan die enigste, absolute waarheid, verhef hulle hulle eie beperkte insigte tot absolute waarheid. Teen hierdie soort arrogansie maak postmoderne teologiese insigte beswaar en stel 'n meer beskeie benadering voor. Waar daar respek is vir die grootheid en omvangrykheid van "die waarheid", sal mense ook beskeie wees oor hulle eie (on)vermoë om dit te verwoord. Elke mens se poging om dit te verwoord, is net 'n beperkte weergawe van "die Christelike waarheid". Elke mens se beperkte weergawe word bepaal en beïnvloed deur byvoorbeeld die denkwêreld waaruit die persoon kom, die kultuur waarin die persoon leef, wat vir die persoon "vanselfsprekende waarhede/werklikhede" is (wat nie noodwendig dieselfde is vir ander mense, selfs uit dieselfde kultuur of geloofsoortuiging nie). Daarby kan nog toegevoeg word: persoonlike ervarings, vooroordele, wanbegrip en leemtes - geen mens is vry van hierdie dinge nie. McLaren (2000:172-173) stel dit soos volg: "I believe Jesus is true, but I don't believe Christianity in any of our versions is true .... I believe there is no completely true version of Christianity anywhere except, of course, in the mind of God."

Beskeidenheid is sekerlik nader aan "die Christelike waarheid" as arrogansie en selfversekerdheid. Indien die vrees vir postmoderne "relativisme" verplaas kan word met waardering vir postmoderne beskeidenheid, sal die Christendom, wat in die geskiedenis baie gruweldade gepleeg het (en vandag nog doen) in die naam van "die waarheid", sekerlik daarby baat. Ook geloof kan baat by beskeidenheid. Seker kennis van 'n 


\section{Postmoderne kerk-wees in die lig van publieke teologie}

absolute waarheid, beteken dat 'n mens reeds weet. Niks meer is nodig nie. Geloof is juis nodig waar 'n mens nie seker kan weet en alles duidelik kan sien nie. Dan bly net geloof en hoop oor (vgl McLaren 2000:173).

Postmoderne suspisie oor mense met mag wat beleid maak en uitvoer om hulle eie belange te pas, harmonieer met wat die Evangelies oor Jesus en sy teenstanders berig. Die Fariseërs is seker van wat hulle weet. Hulle is seker dat hulle reg is. Daarom meen hulle dat dit geregverdig is om hulle "absolute waarheid oor God" op ander af te dwing.

Ook verdraagsaamheid waarvoor postmoderne denke pleit, harmonieer met die evangelie. Hedendaagse Christene is egter soms bang dat "te veel" verdraagsaamheid van "ander" waardes, Christelike waardes in gevaar sal stel. Mike Regele (1995:216) wys egter uit dat verdraagsaamheid juis 'n verhouding kan skep wat vir Christene die geleentheid bied om naas al die ander verhale ook met vrymoedigheid die Christelike verhaal te vertel. Dit is vir hom "the opportunity to proclaim again the story of Jesus, and the hope of life that is in him alone, will open before us. It is the unsurpassable story. No other story answers the question, What is life? or the question, Where is meaning to be found?" Onverdraagsame pogings om Christelike waardes te beskerm teen of af te dwing op ander, maak so 'n "evangelisasie-geleentheid" onmoontlik. Onverdraagsame houdings en gedrag kom nie ooreen met evangeliese waardes nie.

Moraliteit is by uitstek ' $n$ terrein waarop Christelike onverdraagsaamheid manifesteer. Omdat sekere sienings beskou is as "reg", het Christene die "reg" om dit op ander af te dwing en is dit "reg" om die wat "oortree", te straf, seer te maak, te ostraseer en te etiketteer. Sulke gedrag wat op groot skaal in kerklike gemeenskappe en regerings aangetref word, kom nie ooreen met die evangelie nie en lyk allermins aantreklik vir mense binne en buite die kerk. Dit is van die redes wat mense aangee waarom hulle geloofsgemeenskappe verlaat en waarom ander nie belangstel om daarby aan te sluit nie. Die Bybel self is nie eenduidig as dit kom by morele voorskrifte nie. Dit is duidelik dat morele kodes oor tyd en kulture heen verander - ook in die Bybel. Met postmoderne insigte ten opsigte van kultuur, verskeidenheid en verandering, kan geloofsgemeenskappe beweeg na 'n meer evangeliese (en realistiese en onbevreesde) gesindheid.

Christene se grootste probleem met postmoderne denke is waarskynlik die ervaring dat alle vastigheid weggeneem is. Vaste sekerhede is 'n kenmerk van moderne denke. Die teologiese probleem daarmee is egter dat geloof ("'n vaste vertroue op die dinge wat ons hoop, 'n bewys van die dinge wat ons nie kan sien nie" - Heb 11:1) in botsing kom met wetenskaplike sekerhede van moderniteit (kyk Newbigin 1995). Vaste sekerheid is, teologies gesproke, iets 
waaroor net God beskik. Mense kan dit nooit bereik nie. Kerk-wees in 'n postmoderne wêreld is om afstand te doen van die illusie van vaste sekerhede en daadwerklik in die geloof verder te gaan.

Die beskeidenheid van postmoderne kerk-wees kan verligting bring vir Christene wat swaar gedra het aan die verantwoordelikheid om die wêreld te evangeliseer. Dit het dikwels nie beteken dat die Christelike boodskap al by mense uitgekom het nie, maar of 'n spesifieke denominasie al op 'n spesifieke plek teenwoordig is. Die agteruitgang van die hoofstroomkerke het ook beteken dat missionêre werk nie meer met dieselfde entoesiasme aangepak is nie. As daar nie eens geld is om te oorleef nie, hoe kan daar geld wees vir missionêre projekte? McLaren (2000:122-124) wys op 'n aantal stuikelblokke vir die missionêre gerigtheid van die kerk. Kerke het toenemend selfgerig geraak. Die "teiken" van die kerk se missionêre werk, die mense van die wêreld, het meer opgelei begin raak. Dit was makliker om minder opgevoede mense te evangeliseer as wat dit is om intellektuele mense te oortuig. Die Christelike godsdiens het oënskynlik nie geslaag nie - nie om self te verbeter of van die wêreld ' $n$ beter plek te maak nie. Die postmoderne wêreld is ' $n$ skeptiese wêreld. Dit is skepties oor die mens se vermoë om enigiets seker te weet. Dit is suspisieus teenoor mense wat met oormatige ywer, selfversekerdheid en selfs fanatisme hulle saak probeer bevorder. Is van die gruwelikste wandade in die geskiedenis nie juis deur sulkes gepleeg nie?

'n Missionêre gerigtheid op die plurale en postmoderne konteks van vandag is inderdaad nie ' $n$ eenvoudige saak nie. Maar daar is ' $n$ ander kant aan die saak. Die postmoderne wêreld is meer oop vir spiritualiteit as wat die moderne wêreld was. Volgens die filosoof Jürgen Habermas (1981, 1987; vgl Janssen 2003:5) was dit juis die taak van modernisme om ontslae te raak van die slegte invloed van godsdiens. Dit was die taak van sekularisasie.

Postmoderniteit het egter ' $n$ wending hierin gebring. Sekularisasie het nie die einde van spiritualiteit beteken nie. Daar is ' $n$ groot en groeiende belangstelling in spiritualiteit - met of sonder die kerk (Avis 2003:108). Publieke teologie se fokus is nie op die tradisionele missionêre taak van die kerk nie, maar eerder op wat God reeds besig is om in die wêreld te doen. Volgens McLaren (2000:183) is die kerk se verantwoordelikheid om daarvoor oop te wees om dit raak te sien en dan te identifiseer hoe die kerk hiermee kan saamwerk.

\section{DIE POSTMODERNE VERSKYNSEL}

Hoewel die begrip "postmodern" algemeen gebruik word vandag, is daar nie werklik duidelikheid oor wat dit presies behels nie. Volgens Wentzel van Huyssteen (1999:29) is postmoderniteit 'n kulturele houding en perspektief 


\section{Postmoderne kerk-wees in die lig van publieke teologie}

eerder as 'n vaste begrip wat liniêr beskryf kan word. Vir James Miller (1989:1-19) is die postmoderne era goed onderweg. Dit kan nie langer ontken of weggedink word nie. Vir John Burkhard (2004:127) verteenwoordig postmoderniteit 'n nuwe wêreldbeeld, beslis vir Westerse kulture en miskien selfs ook vir die hele wêreld.

Die begrip "postmodern" word sedert die 1970s toenemend gebruik in die literatuur - eers in literêre kritiek, daarna in argitektuur en later in filosofie, sosiale en kulturele analise en teologie (Hymann 2002:11-19; kyk Anderson 1998). Hoewel dit eers redelik onlangs algemeen gebruik word, lê die wortels van die begrip verder terug, naamlik in die filosofiese werk van Friedrich Nietzsche (1844-1900) en Martin Heidegger (1889-1976). Heidegger se hermeneutiese denke het aanleiding gegee tot die Franse dekonstruksieteorie waarvan Jacques Derrida (1930-2005) (kyk Dillon [1995] 1999:223) waarskynlik die bekendste eksponent is. Michel Foucault (1926-1984) met sy histories-sosiologiese werke oor malheid, die moderne strafstelsel, mag en seksualiteit (kyk Gutting [1995] 1999:320-321) en Jean-Francois Lyotard met sy 1979 werk, The postmodern condition: A report on knowledge, het verdere momentum verleen aan postmoderne denke.

J E L (Lesslie) Newbigin (1909-1998) het na 38 jaar diens in Indië teruggekeer na Engeland om daar 'n veranderde kultuur aan te tref. Indien die kerk iets te sê wil hê in hierdie kultuur, het hy gemeen dat dit noodsaaklik is om die wortels van die (post)moderne kultuur te verstaan (kyk Newbigin 1985; Newbigin \& Weston 2006). Volgens De Reuver (2004:233) was dit Newbigin se oortuiging dat die Christelike teologie alleenlik vanuit so 'n letterlik "radikale" vertrekpunt werklik iets te sê sal kan hê in die publieke sfeer. Vir Newbigin (kyk 1985; 1991:15-39, 45-55; 1994a:80-97, 107-122, 142-146, 161 e v, 203-205) is die armoede van die moderne Westerse kultuur dat dit nie in staat was om bevredigende antwoorde te gee op die groot vrae waarmee die Westerse wêreld worstel nie. Die probleem is moderne denke se onderliggende siening van kennis. Dit is naamlik gebaseer op 'n rasionaliteit wat bou op sogenaamde "verifieerbare feite" wat verkry word deur middel van objektiewe ondersoekmetodes. Hierdie siening lei tot die splitsing objek/subjek en objektiewe/subjektiewe kennis. Kennis van God kan nie op 'n objektiewe manier verwerf word nie. Die filosoof Immanuel Kant (1724-1804) het volgens Newbigin (in De Reuver 2004:248) probeer om kennis van die geloof in God "veilig" buite bereik van die wetenskap te plaas, maar al wat hy daarmee bereik het, was om geloof en kennis te skei en die idee te vestig dat kennis van God onmoontlik is. Op grond van hierdie siening van kennis, kom Nietzsche, volgens Newbigin (1994b:17, 33; kyk [1978] 1995:26; 1996:63; vgl Bloom 1988), tot die gevolgtrekking dat geen objektiewe kennis van die 
waarheid moontlik is nie. Moderniteit was op soek na kennis wat sekerheid sou gee. Wat dit bereik het, was om daarby uit te kom dat absolute kennis en universele waarheid onmoontlik is om met die rede te vind. Volgens Newbigin (1995:27) is hierdie proses die oorsaak van die doodloopstraat waarin die westerse kultuur verkeer. ' $n$ Nuwe postkritiese filosofie is nodig om as grondslag te dien om weer hoop te vind en tot kennis te kom in ' $n$ veranderde wêreld (kyk De Reuver 2004:249).

Die vraag is of postmoderne denke net ' $n$ uitloper is van laat moderniteit, 'n soort verlengstuk van die moderne gees (kyk Habermas 1987; Taylor 1989, 1991, 1999:13-37; Wellmer 1991; Thornhill 2000) en of dit werklik 'n nuwe beweging verteenwoordig. Laasgenoemde standpunt is volgens Burkhard (2004:129) toenemend besig om veld te wen. Hy meen dat postmoderniteit sowel 'n positiewe as 'n negatiewe reaksie op moderniteit verteenwoordig. Dit verwerp moderniteit nie totaal nie en is ook nie 'n poging om terug te keer na 'n vroeër era, waarmee die winste van moderniteit (bv menseregte, demokrasie, onderwys vir almal, mediese en tegnologiese vooruitgang, die bevryding van vroue) verlore sal gaan nie. Burkhard (2004:130-145) fokus op vyf kenmerke van postmoderniteit wat kortliks hier bespreek word.

\section{- $\quad$ Verwerping van 'n dualistiese wêreldbeeld ${ }^{1}$}

Moderne denke hou nou verband met die opkoms van die (natuur)wetenskap. Moderne wetenskap het die metode van objektiewe waarneming ontwikkel. Daarom was dit nodig om skerp te onderskei tussen die "objek" en die "subjek". Wetenskap het te doen met die objektiewe, fisiese, empiriese werklikheid en die mens met die subjektiewe, geestelike werklikheid. Kennis is geplaas by die objektiewe, wetenskaplike en kenbare. Die subjektiewe sfeer van gevoelens, verbeelding, waardes en geloof, dus die terreine van politiek, kuns, godsdiens en etiek is nie beskou as bronne van waardevolle kennis nie. Hierdie splitsing tussen feite en waardes het daartoe gelei dat net feite geldig geag word in die publieke wêreld van die rede, terwyl alles wat met waardes te doen het gerelegeer word tot die private sfeer waar elkeen se individuele subjektiewe waarheid geldig is. In die publieke wêreld waar die rasionele heers, is daar één waarheid, gebaseer op feite en in die private wêreld waar die subjektiewe heers, is daar ' $n$ onbeperkte pluraliteit van waarhede. Die subjektiewe waarheid kan nie geken word nie (De Reuver 2004:259; kyk Newbigin 1987:14-41; 1991:1-13; 1994a:98-112; 1994b:1-19; 1995b:16-28). Volgens Newbigin (1994b:17-24) is dit hierdie pluraliteit in die sfeer van

\footnotetext{
${ }^{1}$ Kyk Burkhard (2004:130-131).
} 


\section{Postmoderne kerk-wees in die lig van publieke teologie}

waardes, wat lei tot relativisme en subjektivisme. De Reuver (2004:259) stel dit soos volg: "Waar persoonlijke waarden en kennis worden verlaagd tot een privé-mening, daar is elke claim op publieke en universele waarheid onmogelijk. Andere machten, met name, de wil tot macht, zullen dit vacuüm dan opvullen, met alle gevolgen van dien."

Postmoderne denke kritiseer die radikale skeiding tussen die objektiewe en die subjektiewe werklikheid. Die skeiding word gesien as skadelik vir die mens en die milieu, want "objekte" kan gemanipuleer, beheers en uitgebuit word. Aan die ander kant word mense toenemend bepaal deur die tegnologie. Die moderne wetenskap word verantwoordelik gehou vir die toestand waarin die wêreld tans verkeer. Postmoderne wetenskap is op soek na 'n nuwe benadering tot die wêreld wat die splitsing tussen mens en wêreld, tussen subjek en objek, sal heelmaak.

\section{- Verwerping van fondamentalisme ${ }^{2}$}

Moderne soeke na "objektiewe kennis" en "die waarheid" het fondamentalisme (foundationalism) (kyk Moser [1995] 1999:321-323; Murphy \& McClendon 1988-1989:192-193; Thiel 1994:17-19, 82-84, 87-88, 94-97; Guardino 1989:241-252; 1990:221-235, 1995/96:57-69) tot gevolg gehad. Fondamentalisme kan soos volg beskryf word (Burkhard 2004:132):

"[F]oundationalism refers to absolutely irreducible principles of knowledge and action whose truth imposes itself with irrefutable evidentiary power. They are 'first' principles, since nothing can precede them, and as such they are unquestioned". In die premoderne wêreld het tradisie die absolute en onaantasbare beginsels verskaf waarop mense se lewens berus het. Word die fondamente bevraagteken, stort alles in duie. In die moderne wetenskap het die soeke na vaste kennis uitgeloop op die formulering van natuurwette en in die filosofie was die menslike rede die vertrekpunt (Burkhard 2004:132). Later ontwikkelinge in die natuurwetenskap soos die kwantumfisika en Einstein se relatiwiteitsteorie, het die "vaste fondamente" geskud. In die filosofie kon die menslike rede ook nie by een absolute waarheid uitkom nie. Postmoderne denke het uitgewys dat enige vorm van fondamentele beginsels eintlik onhoudbaar is.

\section{- $\quad$ Verwerping van totalisering ${ }^{3}$}

Die moderne ideaal was om een sisteem te vind wat die werklikheid volledig kan verklaar. Alles wat teen so 'n denksisteem ingaan, is minderwaardig en

\footnotetext{
${ }^{2}$ Kyk Burkhard (2004:131-133).

${ }^{3}$ Kyk Burkhard (2004:133-135).
} 
onvoldoende. So 'n sisteem is byvoorbeeld bedink deur Karl Marx. Op politieke gebied is die reg wat moderne nasies hulleself veroorloof het om ander se grondgebied te konfiskeer en die natuurlike hulpbronne vir hulleself te vat, voorbeeld van totaliserende denke. Verdere voorbeelde is Nazi Duitsland en Kommunisme.

Totaliserende sisteme gaan altyd gepaard met kragtige verhale of narratiewe wat bevestig dat hulle die mag en die reg het om hulle ideale ten alle koste te verwesenlik. Die doel van sulke "metanarratiewe" of "meesterverhale" is volgens Hyman (2002:78) "to 'explain' and 'position' everything, that is, every other narrative and every other interpretation of the world." Versteek agter die meesternarratiewe is ideologie en daarom kan meesternarratiewe nie alternatiewe verhale verdra of ander stemme toelaat nie. Alles en almal moet inpas by die sisteem, anders wankel die sisteem. Die ideologie is dat die sisteem tot almal se beswil is.

Moderniteit se meesternarratief is dié van onbeperkte menslike vooruitgang. Mense kan verbeter word, kan gelukkig wees, kan konflik in die wêreld uitskakel, kan vir alle wêreldburgers welvaart bewerkstellig. Die verhaal is egter misleidend, want die werklikheid lyk anders. Daar is oorlog en hele volke word uitgewis; daar is 'n groter wordende gaping tussen arm en ryk; die meeste mense in die wêreld ly honger en beskik nie oor basiese middele nie; die aarde word verwoes en hulpbronne uitgeput; mense is uitgelewer aan ekonomiese kragte. Godsdienstige meesterverhale spreek van vrede en liefde, maar juis binne godsdienste word onverdraagsaamheid, vervolging, heksejagte en die verkettering van ander aangetref.

Postmoderne denke het 'n hermeneutiek van suspisie ontwikkel om die onderliggende vooroordeel en manipulasie van die meesterverhale te ontmasker (Burkhard 2004:134). Godsdiens word byvoorbeeld ontmasker as self-gerig, onverdraagsaam en misleidend. Godsdiens is nie bevrydend nie. Postmoderne denke beklemtoon dat alle verhale gehoor moet word, nie net die van die magtiges en bevoorregtes nie.

\section{- $\quad$ Die bedreiging van nihilisme ${ }^{4}$}

As daar geen vaste fondamente en absolute waarhede, geen totaliserende sisteme meer kan wees in 'n postmoderne wêreld nie, is die vrees dat algehele relativisme oorgeneem het en algehele nihilisme die gevolg sal wees. Postmoderne denke wil egter juis nie 'n totaliserende sisteem bied waar daar net ruimte is vir een storie nie. Relativisme, sinloosheid, leegheid en 'n algehele gebrek aan waardes mag die inhoud van sekere postmoderne

\footnotetext{
${ }^{4}$ Kyk Burkhard (2004:135-139).
} 


\title{
Postmoderne kerk-wees in die lig van publieke teologie
}

verhale wees. Maar binne postmoderne denke is daar ruimte vir ander stemme, dus ook vir verhale van sin en betekenis, van waarde, lewe en doelgerigtheid. Die Christelike verhaal van lewe-gewende dood en transformerende opstanding, van bevryding en versoening kan nie ontken en Christelike stemme stilgemaak word nie, anders sou postmoderniteit teen sigself ingaan (Burkhard 2004:138-139). Moderniteit het probeer om die Christelike geloof ondergeskik te maak aan die moderne siening van rasionaliteit. Miskien het die groot bedreiging vir die Christelike geloof juis hier gelê. Postmoderniteit, aan die ander kant, kan geloof nie probeer uitsluit of tot niet maak nie. Dit word dan selfs moontlik dat die Christelike verhaal en verhale van nihilisme en sinloosheid met mekaar in dialoog kan gaan. Afrikadenke fokus op persoonskap as die kollektief van individuele, sosiale en goddelike dimensies wat saamgebind word deur liefde, hoop en 'n sinservaring (Lartey 2006:142). Waar hierdie samebinding disintegreer, is daar 'n verval tot nihilisme. Cornel West (1994:22-23) stel dit soos volg:

\begin{abstract}
Nihilism is to be understood here not as a philosophic doctrine that there are no rational grounds for legitimate standards of authority; it is, far more, the lived experience of coping with a life of horrifying meaninglessness, hopelessness, and (most imporant) lovelessness. The frightening result is a numbing detachment from others and a self-destructive disposition toward the world. Life without meaning, hope, and love breeds a coldhearted, meanspirited outlook that destroys both the individual and others.
\end{abstract}

Die taak van publieke teologie is dat mense sin, hoop en liefde sal vind sodat hulle outentiek kan leef as individue en as mense-met-ander.

\section{- Relasionaliteit ${ }^{5}$}

In moderne denke staan die mens as subjek sentraal (kyk Murphy 1990:200201). Waar nadenke oor kennis in die premoderne era gesentreer het op die kosmos en filosofiese denke gefokus het op die metafisiese, word die individuele, selfstandige mens in moderne denke die sentrum. Postmoderne denke plaas die klem op die mens-in-verhouding eerder as op die mens as individu. In plaas van kennis as feite waaruit die werklikheid bestaan, wil postmoderne denke die werklikheid holisties benader (kyk Murphy \& McClendon 1988/89:199-201). Kennis word verkry deur mense wat saamwerk, eerder as individuele kenners.

\footnotetext{
${ }^{5}$ Kyk Burkhard (2004:139-145).
} 
Die postmoderne mens as subjek is die mens wat nadink oor die Ander (kyk Levinas [1961] 1969; [1974] 1981; Ricoeur 1992:188-189, 338-340; Stiver 2001:81; cf Volf 1996), en die mens-in-verhouding (kyk Buber 1958; vgl Macmurray [1957] 1966, [1961] 1967; Seeskin [1995] 1999:104; Burkhard 2004:140). Sonder die ander is outentieke menslike bestaan onmoontlik. Die ander doen nie afbreuk aan 'n mens se mens-wees nie, maar dra juis daartoe by. Die ander is intrinsiek deel van 'n mens se mens-wees (kyk Davis 1996; Peperzak 1997; Kearney 2001:62-69). "Die Ander" is die menslike Ander én die transendente Ander. Vanuit 'n Christelike perspektief sien Burkhard (2004:144) postmoderne denke soos volg:

... far from being entirely hostile to a Christian anthropological view,
postmodernity opens up new possibilities of thought for Christian
thinkers in arguing for an understanding of the human being
different from that of modernity. Postmodernism shows ifself to be
less than entirely bent on nihilistic and anti-rational tendencies. It
need not be destructive. In fact, postmodernism can be used in
constructive ways.

Al vyf bogenoemde aspekte van die "postmoderne verskynsel" staan in noue verband met die rol wat die insig in "pluraliteit" in hedendaagse denke speel. Pluraliteit is ' $n$ belangrike faset van postmoderniteit. Dit word dikwels gesien as ' $n$ bedreiging, veral onder Christene wat bang is dat dit nie versoenbaar is met hulle geloof nie. Calvin Shrag ([1995] 1999:714) beskryf pluraliteit as 'n perspektief op die wêreld wat diversiteit eerder as enersheid beklemtoon en meervoudigheid eerder as eenheid. Hy meen dat pluraliteit teen sowel 'n monistiese (klem op die één tot die uitsluiting van baie) as 'n dualistiese (twee teenoorstaande sfere) verstaan van die wêreld ingaan. Pluraliteit beskou die wêreld as heterogeen. Dit soek nie antwoorde oor die "wesenlike" (essensie) of "kenmerke" van sake nie, maar is meer geïnteresseerd in die groot verskeidenheid sosiale praktyke en die verskillende rolle wat taal, diskoers en die narratief speel in mense se werklikheid (Schrag 1999:715). Postmoderne denke aanvaar nie moderniteit se idee dat die werklikheid óf objektief kenbaar is en deur die wetenskap verduidelik kan word, óf subjektief is en daarom onkenbaar is en alleenlik behoort tot die private sfeer nie. Pluraliteit waak teen reduksie van die werklikheid en absolute waarheidsaansprake: "dit is so en nie anders nie". Deur middel van 'n hermeneutiek van suspisie wil dit enige sweem van ideologiese verwringing aan die kaak stel. Dit is ook suspisieus oor enige vorm van sistematiese beredenering wat lei tot "gevolgtrekkings". Dit plaas ' $n$ hoë premie op verdraagsaamheid. Dit wil nie oordeel nie en verdra nie meerderwaardigheid nie. 


\section{Postmoderne kerk-wees in die lig van publieke teologie}

Die Duitse Rooms-Katolieke teoloog Heinrich Fries (1969:3-4) beskryf "pluralisme" reeds in 1969 soos volg: "Pluralism' expresses the fact that in the various areas of human existence multiplicity, plurality, is the dominant factor. Pluralism is the side-by-side-ness of the many." Vir die Christelike godsdiens beteken pluraliteit dat die Christelike geloof en kerk nie langer die een en al is in die Westerse wêreld nie, maar een van vele. Dit is nie langer die dominante invloed in die Westerse samelewing nie en beklee nie meer 'n bevoorregte posisie nie (Fries 1969:11).

Volgens Fries (1969:17) is dit nie nodig om pluraliteit as 'n bedreiging te sien nie. Dit is moontlik om pluraliteit te aanvaar as deel van die moderne samelewing sonder om te verval in godsdienstige relativisme en wat kenmerkend Christelik is, te verloor. Die insigte van pluraliteit oor die menslike bestaan, kan juis 'n dringende oproep doen op die kerk om van diens te wees in 'n antroposentriese wêreld (Burkhard 2004:153). Dit sal die Christelike geloof eerder goed doen as kwaad as die kerk sou ophou om te kompeteer met, mag uit te oefen oor en antagonisties op te tree teenoor ander gelowiges, maar eerder respekvol luister na waardevolle insigte van ander en in dialoog tree met hulle. Vir John Burkhard (2004:159) kom "postmoderne Christelike teologie" daarop neer dat pluraliteit binne die Christelike teologie en denke aanvaar word as 'n werklikheid, terwyl Christene wat nie noodwendig dieselfde dink oor alles nie, steeds binne dieselfde geloofsfamilie bly. Die kerk is pluraal van aard. God se een waarheid kom juis tot uitdrukking in die dialoog van baie getuienisse. Dingemans (1987:183) stel dit soos volg: "Dialoog is een hermeneutisch begrip; het betekent zoiets als in de kring van gelovigen stappen en binnen die context, horen naar het Woord, zoeken naar antwoorden, samen toetsen welke antwoorden houdbaar zijn en jezelf laten corrigeren."

Vir Dingemans is die kerk nie in die eerste plek daar waar "die suiwer leer" geformuleer en verkondig word nie, maar daar waar reg geleef word in liefde. Hy onderskei drie legitieme vorme van kerk-wees (Dingemans 1988:133-135). Die eerste is 'n sakramentele vorm waar eenheid met God ervaar word in die viering en aanbidding van die nagmaal. Die tweede is 'n dienende gestalte van die kerk wat aktief deelneem aan en betrokke raak by die alledaagse lewe. Die derde vorm van kerk-wees is die van kontemplasie en meditasie waar mense individueel en gesamentlik God se stem hoor in die fluistering van die windstilte. In elke hart werk die Heilige Gees om mense afsonderlik te bring tot 'n eie verhouding met, belewing van en lewe in die teenwoordigheid van God. K Runia (1989:42-44) vra krities of Dingemans nie te idealisties is nie. Is daar grense aan pluraliteit? Is een belydenis nie noodsaaklik vir mense om eenheid in die geloof te kan hê nie? Wat is die 
kriteria vir eenheid binne die pluraliteit wat Dingemans voorstaan? Laastens wonder hy of Dingemans se dialoog wel werk in die praktyk en, indien wel, waar? In denominasies? In gemeentes?

Dingemans (1989:1982-1983) antwoord deur te onderskei tussen "pluralisme" en "pluriformiteit". Laasgenoemde hef nie die Christelike identiteit op nie. Dit impliseer nie 'n pluraliteit waar elkeen op sy of haar eie manier probeer salig word nie. Maar binne die Christelike identiteit moet daar ruimte wees vir 'n verskeidenheid maniere om uiting te gee aan geloof. Indien daardie ruimte nie daar is nie, vrees Dingemans (1989:182-183) die gevolge: "Ik ben doodsbenauwd voor een opgelegde uniformiteit, zeker als het gaat om het heiligste wat mij inspireert en op de been houdt. Eenheid, en vooral organisatorische eenheid moet geen christelijke ideologie worden, geen dekmantel die alles versluiert." Die eenheid van die kerk lê daarin dat almal volgelinge van Jesus Christus is en die waarheid in Christus ontvang het (De Reuver 2004:233). Die waarheid beteken verskillende dinge vir verskillende mense. Die waarheid word op verskillende maniere gevier. Van die waarheid word met verskillende stemme en klemtone getuig. Dingemans (2001:276301) gebruik die beeld van 'n "ronde tafel kerk". Dit is waar God en mens ontmoet en Jesus gedenk word. Almal is welkom aan tafel en die gawes word aan almal uitgedeel. Die tafelgemeenskap is 'n pluriforme een. Dit gaan nie daarom dat almal dieselfde moet dink en klink nie, maar dat hulle saam in gesprek soek na die waarheid van God vir hulle onderskeie en gemeenskaplike lewens. Daar is spanning in hierdie eenheid. Dit is "een spannende gemeenskap, een kerk waarin de zaak steeds op spanning wordt door de confrontatie met het evangelie en met elkaar" (Dingemans 2001:286). Volgens Dingemans (2002:142) is die kerk 'n kruispunt waar God en mens, tradisie en wêreld, uitdaging en werklikheid mekaar ontmoet. Op hierdie kruispunt staan die publieke teologie.

Volgens Burkhard (2004:160) is die pluraliteit van postmoderniteit heelwat vriendeliker teenoor die Christelike geloof as die vyandigheid teenoor die Christelike en ander georganiseerde godsdienste, die anti-tradisionalisme en anti-dogmatisme van moderniteit. Die nuwe waardering vir die taal van die Bybel, beelde en narratiewe kan 'n vrugbare ontmoeting met postmoderne denke moontlik maak - veral die soort postmoderne denke wat minder negatief en relativisties is. Burkhard (2004:160-163) bespreek die positiewe bydrae van postmoderne denke tot die Christelike teologie. Christelike postmoderne denke is oop daarvoor om meesternarratiewe wat ander kleiner verhale wil doodsmoor en uitsluit, met suspisie te benader. Die postmoderne Christelike kerk fokus nie net op "identiteit" en enersheid nie, maar is oop vir 


\section{Postmoderne kerk-wees in die lig van publieke teologie}

verandering, ontwikkeling en bekering - nie net as individue nie, maar ook van institute. Daar is 'n balans tussen stabiliteit en veranderlikheid.

Postmoderne Christelike teologie is nie beperk tot harde feite nie, maar het ruimte vir die kompleksiteit, rykdom en misterie van God se skepping. Daar is ruimte vir 'n groter werklikheid as net wat die menslike verstand kan vasvat en daarom ook vir die verskeidenheid van verduidelikings en interpretasies van daardie werklikheid. Die pluraliteit van kulture, godsdienste, mense en gelowiges staan voor die uitdaging om die onderliggende eenheid, integriteit en betekenisvolheid van dit alles te ervaar (kyk Sauter 1995; Van der Ven 1996:97-98). Hierdie vorm van eenheid wat Burkhard (2004:163) 'n "weak unity" noem, bied volgens hom die moontlikheid om dialoog te voer met ander en 'n postmoderne wêreld uit te nooi om die waardes van die evangelie te deel. Publieke teologie skep die moontlikheid vir so 'n dialoog.

\section{KENMERKE VAN PUBLIEKE TEOLOGIE}

'n Publieke teologie het 'n drieledige taak: om die publiek in te sluit by teologiebeoefening; om ook oor die alledaagse na te dink in die teologiese refleksie; om die dialoog tussen teologie en die hedendaagse kultuur te fasiliteer. Die hedendaagse kultuur met wortels in die denke van die Verligting wat op die rede bou en alles rasioneel in twyfel trek, is 'n plurale kultuur. Newbigin (1987:3) beskryf kultuur as "the sum total of ways of living developed by a group of human beings and handed on from generation to generation". Wanneer die plurale kultuur geen hoop te bied het nie, moet 'n ander "way of living" ontwikkel word. Newbigin (kyk 1985:74-75; 1987:146148) wys nie die pluraliteit van kultuur af nie. Juis in die dialoog van 'n verskeidenheid uitdrukkingsvorme van geloof, kan geloof hoop bied aan 'n plurale kultuur. In pluraliteit lê potensieel die rykdom en nie die leemte van die Christelike geloof nie.

Die kerk as instelling is aan die kwyn. Sosioloë sien dit as die laaste fase in die proses van sekularisasie. Die sosioloog Max Weber ([1947] 1968:246-254) het al gepraat van die "onttowering" van die wêreldbeeld. In vroeëre tye het (goddelike) magte en kragte 'n groot rol gespeel in hoe mense die wêreld rondom hulle gesien het. Sedert die Verligting het mense se siening van hulle wêreld meer rasioneel geword (moderne denke). Die ontwikkeling van die natuurwetenskappe het veral daartoe bygedra dat verskynsels in die wêreld wetenskaplik verklaar word eerder as om dit toe te skryf aan onsigbare magte en kragte.

Die "onttowering" van die wêreldbeeld het gelei tot spanning tussen wetenskap en die tradisionele geloof in God. Is God in beheer van die wêreld of is die voortgang van dinge afhanklik van natuurlike wetmatighede en 
meganismes? Siekte word byvoorbeeld nie meer bestry met gebed en handoplegging nie, maar deur mediese ingrepe.

In 'n gedifferensieerde en gekompliseerde samelewing is daar nie eintlik meer "een wêreldbeeld", 'n samehang van dinge, één visie nie. In die verlede het die kerk aan so 'n één visie inhoud gegee. Die filosoof Lyotard het gesê dat "die groot verhaal" verdwyn het. In die plek daarvan het klein verhale, persoonlike stories gekom. Sekularisasie beteken nie net dat die kerk die rol om die groot verhaal te bepaal, verloor het nie. Dit beteken ook dat 'n geheelvisie op die wêreld verdwyn het. Sekularisasie gaan nie oor veranderinge wat plaasvind in ' $n$ samelewing nie. Dit is verandering van die samelewing self, van die basiese organisasie van die samelewing. Sommige verandering is doelbewus, byvoorbeeld die wegneem van mag uit die hande van die "ampte" en om meer mag toe te ken aan "leke". Ander veranderings is weer geleidelik en onbewus, soos byvoorbeeld toenemend minder verwysing na die bo-natuurlike in die alledaagse lewe. Dit wil sê, sekularisasie verwys na die proses waar religieuse instellings, aksies en ' $n$ religieuse bewussyn sosiaal toenemend minder belangrik word in die sosiale sisteem. Drie voorbeelde van hoe sekularisasie in spesifieke kontekste manifesteer, met ander woorde hoe religie toenemend van minder belang word, is die volgende:

- In Swede is die kerk feitlik 'n departement van die staat, word ondersteun met belastinggeld, staan finansieel sterk, maar kerkbywoning is swak.

- In Brittanje is die kerk nog in assosiasie met die staat, maar ontvang geen staatsbefondsing nie. Kerkbywoning is nie heeltemal so swak soos in Swede nie, maar persoonlike bydraes is min.

- In die VSA is kerk en staat geskei, maar kerkbywoning en bydraes is hoog.

- Vir Afrikaners was godsdiens en kultuur nog altyd onlosmaaklik verbonde (Christelik-nasionaal). Vorme soos die opening van skole, vergaderings, die parlement met gebed, Sondag-wetgewing, ensomeer, is gehandhaaf, maar mense was nie noodwendig spiritueel nie.

Sekularisasie is die produk van moderne denke. Vir 'n kritiese denker soos die filosoof Jürgen Habermas $(1981,1987)$, was dit onaanvaarbaar dat die kerk 


\section{Postmoderne kerk-wees in die lig van publieke teologie}

as instituut soveel te sê gehad het sonder om juis waarde toe te voeg tot die samelewing. Daarom was die laaste taak van moderniteit volgens hom om ontslae te raak van die knelgreep van die kerk.

Is dit moontlik om so radikaal nuut te dink oor kerk dat die verdwyning van die kerk in 'n postmoderne wêreld nie 'n noodwendigheid hoef te wees nie? Om nuut te dink oor kerk-wees vereis nuwe perspektiewe:

- Moderne denke is dualisties: kerk/wêreld, binne/buite die kerk, kerk/sekte. Hoewel die kerk probeer het om apart te bly van alles wat wêrelds is, het juis wêreldse/kulturele norme aan kerklike norme vorm gegee. Dit is burgerlike godsdiens. Publieke teologie is nie burgerlike godsdiens nie. Dit sê dat die kerk deel is van die wêreld (nie teenoor nie) en dat teologie ook in die wêreld (nie net in die kerk nie) beoefen moet word.

- Moderne denke beklemtoon één absolute waarheid en onderbeklemtoon 'n verskeidenheid van perspektiewe op die waarheid. 'n Voorbeeld van moderne taal is hoe die NGB die kerk beskryf as: die "ware kerk" wat alleen gevind word waar die Woord "suiwer" verkondig word, die sakramente "reg" bedien word en die tug uitgeoefen word. Dit staan bekend as "totalitêre denke" omdat dit nie ander moontlikhede toelaat nie. Publieke teologie gee ruimte vir ander denke oor kerkwees. Kerk kan ook wees waar dinge anders gedoen word as hier by ons.

- Ruimte beteken nie "relativisme" nie. Publieke teologie wil nie 'n waarde-vrye ("waarde-lose") perspektief voorstaan nie. Wanneer verskeidenheid erken word, is dit juis 'n groot uitdaging vir gelowiges om hulle duidelik te verantwoord oor hulle waardes - hoekom hulle wil wees waar hulle is. Hulle maak 'n bewuste keuse vir waar hulle hulle bevind binne die groot diversiteit en vind waarde in hulle staanplek.

- Wie seker is oor hulle eie staanplek en waardes, kan onbedreig ekumenies deelneem en verryk word deur ander perspektiewe. Publieke teologie bied 'n dinkraamwerk vir hoe om jouself te wees binne 'n ekumeniese konteks.

Byvoorbeeld: My plek van keuse is dié van kerklike teoloog, wat my tuis voel in die teologie van 'n spesifieke kerk. My taak is nie om hierdie teologie teen ander te verdedig nie, maar om die gesprek met ander te fasiliteer. Dit is nie om die Ander te probeer oorhaal tot my 
standpunt of voor te gee dat my teologie die "enigste ware" is nie. Maar omdat hierdie spesifieke teologie myns insiens "waardevol" is, glo ek dat dit waarde kan toevoeg vir ander, soos ander s'n kan waarde toevoeg vir my. Daarom staan ek gesprek voor ter wille van wedersydse verryking.

Publieke teologie bring ons in verhouding met spirituele mense wat hulle nie noodwendig tuis voel binne die institusionele kerk nie. Daarvoor is die volgende nodig:

- Kerke kan nie aan die status quo vasklem nie, maar behoort altyd hervormend te wees: terug na die evangelie, na die kern van die saak, maar met ruimte vir ander.

- Die eenheid van die kerk binne die nuwe situasie (postmodern en postsekularisasie) behoort nuut bedink te word. Dit is nie om ander te probeer eners maak aan jou kerk/teologie nie. Dit gaan eerder oor hoe almal saam kan bydra tot 'n beter wêreld. Lartey (2006:117) verwoord dit soos volg: "God is the God of the other who will remain other in authentic difference .... The otherness of other humans will not be overcome by assimilation into our likeness." So 'n kerk sal respek vir die andersheid van ander hê, maar kan ook verder kyk as andersheid, want andersheid word oorstyg in God. Volgens Larry K Graham (1997:176) is God groot genoeg om elkeen toe te laat om hulleself te wees, eerder as iets anders. As die kerk God se liefde wil weerspieël, is dit hoe die kerk ook behoort te wees. Vir hom is "beeld van God" wees in die wêreld waarin die kerk leef "to ferociously protect and tenderly cherish the uniqueness of each entity in the world, while seeking the conditions of justice in which each might be fulfilled" (Graham 1997:177).

- Onderskei tussen kerklike tradisies en die Christelike Tradisie (evangelie). Tuis in jou eie tradisie, fokus jy op die evangelie. Vir Dingemans (2001:280) lê die eenheid van die plurale kerk in die mistieke verhouding met Christus. ' $n$ Kerk wat nie so een is met en in Christus nie, verloor die eie identiteit en die reg om met ander oor Christus te praat. De Reuver (2004:229) bespreek Dingemans se klem op die Skrif wat die ruimte bepaal van "het pluriforme antwoord van de gelovige van alle tijden". Hy wys daarop dat Dingemans die wetenskaplike interpretasie van die Bybelteks as grens stel vir omgaan met die Skrif. So 'n hermeneutiese uitgangspunt vra van diverse 
Skrifinterpretasies om verantwoord en relevant te wees vir die wêreld waarbinne dit as gids wil dien.

- Dit alles beteken dat die fokus van teologiese opleiding verskuif. Dit is dan nie tegniese opleiding waar "dié antwoorde" geleer word nie, maar is 'n vars soeke na die evangelie vir die huidige tydsgees. Lartey (2006:114-115) noem dit "an appropriate and creative uncertainty that lies at the heart of theological discourse." Hy beklemtoon dat teologiese taal die taal van doksologie en aanbidding is en nie die taal van dominansie en gedwonge eenheidsdenke nie. As teologiese opleiding ontbreek aan spiritualiteit, is die siel daarvan dood. God nooi uit. God dwing nie. Die respons van mense is om in gebed en aanbidding verhouding met God te soek eerder as om God te probeer verstaan met kennis (vgl Mellert 1975; Cobb \& Griffin 1976)

- Die Christelike apologie kry 'n ander rol. Voorheen het dit gevestigde waarhede verduidelik en verdedig. Nou gaan dit om nadenke oor nuwe maniere om die evangelie in die nuwe situasie te kommunikeer. Die lyding van mense en die tragedies en traumas van die lewe kan nie bevredigend beantwoord word met netjies afgeronde teologiese verduidelikings nie. Om nie alle antwoorde gereed te hê nie, is nie 'n swakheid van die teologie nie. Inteendeel, meen Lartey (2006:104): "Given the awesomeness of the theological endeavour a degree of uncertainty is always appropriate." Ambler (1995:94-98) verwoord 'n moontlikheid vir die wêreld van vandag om om te gaan met die vraag: Waar is God? God is "beyond", verby enigiets wat mense kan bedink of vasvang, kan ken of verstaan. God is hier, naby en teenwoordig, nie ver weg van mense en hulle lewens nie. Maar God is nie teenwoordig soos 'n objek teenwoordig is nie. God is teenwoordig in 'n ander dimensie, op 'n ander manier. Lartey (2006:105) beskryf dit as: "One who is closer than a breath and yet further than a cloud." God is ook vóór ons. Ambler (1995:198) stel dit soos volg: "God comes to us, not so much out of the past, calling us back to where we were, but out of the future, beckoning us to a new world, that we ourselves must help to create."

Christelike apologie vir die hedendaagse wêreld, stel McLaren (2000:213) voor, is iets soos om 'n vraag aan nie-Christene te stel en dan stil te bly en te luister sodat hulle jou kan leer van apologetiek. Dit kan wees vrae soos: Glo jy in God? Waarom glo jy of glo jy nie? Wat is vir jou aanvaarbaar en wat is onaanvaarbaar van Christene? As jy 'n 
kerk sou soek, waarna sou jy soek? Wat sou jou kon motiveer om 'n kerk te gaan soek? Hoekom behoort enigiemand in God te glo? Wat is die konsekwensies daarvan as 'n mens nie in God sou glo nie? Wat van jou godsdienstige agtergrond as kind help jou om in God te glo of verhinder geloof soos wat jy ouer word?

- 'n Nuwe taal is nodig. "Ou kerklike taal" word al hoe minder effektief in die nuwe wêreld. 'n Nuwe en gepaste taal word gesoek om ou waarhede te kommunikeer. Dit sluit nuwe taal vir liturgie en rituele in. Die roeping van die kerk om die boodskap te bring, sentreer om die kruis. Dit gaan nie om 'n nuwe vorm van teokrasie nie en ook nie om die groei of die heerskappy van die kerk as instituut nie. Dit gaan om 'n gemeenskap wat leef vanuit die heerskappy van Christus. So 'n lewe is nie een van oorheersing nie, maar 'n lewe van lyding. Wie getuig van die opstanding sal in botsing kom met die magte en kragte van die wêreld en sal ly (De Reuver 2004:257; vgl Newbigin 1989:37-46). As dit die kerk se lewe is, sal die kerklike taal en strukture so wees dat dit uitgeleef kan word. Vir De Reuver (2004:257-258) is dit ' $n$ kerk van lofprysing, 'n kerk wat 'n oog het vir die nood van ander, wat mense toerus vir hulle diens in die wêreld, wat vir mekaar verantwoordelikheid aanvaar, wat hoop bring in 'n wêreld wat nie veel hoop ken nie.

- Die "ampskerk"-idee was deel van die vorige dinkraamwerk. Ed Farley (1987:1-26) en ander (vgl Lambourne 1974; Wilson 1988) spreek kritiek uit op wat Farley die "clerical paradigm" noem. So 'n ampskerklike siening beperk die bediening tot die aktiwiteite van individue (ampsdraers). Die gemeenskap van die gelowiges en hulle werk in die wêreld word prakties buite rekening gelaat. Veral Graham (1996), Miller-McLemore \& Austern (1999) en Lartey (2003, 2006:2627) dui aan hoe hierdie fokus op die kerk se wêreld baie stemme stilgemaak het. In 'n kerk wat effektief en relevant wil wees in 'n postmoderne dinkraamwerk (wat juis voorheen gemarginaliseerde stemme tot spreke wil bring) sal nuut gedink moet word oor die bediening, leierskap en hulpbronne (bv waar geld vandaan kom, samewerking oor grense heen, ens). In so 'n kerk sal almal aktief hulle liefde vir God en ander uitleef ook op gebiede wat tradisioneel die terrein van geordende ampsdraers alleen was, soos gebed, aanbidding, verkondiging en geloofsonderrig. God se sorg vir mense sal weerspieël word in mense se sorg vir mekaar (kyk Lartey 2006:27). Elaine Graham (1996:7) verwoord dit soos volg: "By focusing on the 
reality of practice, we are able to recognize that theory and practice do not exist independently. Metaphysical principles require concrete human agency. The arena of Christian praxis - value-directed and value-laden action - is understood as the medium through which the Christian community embodies and enacts its fundamental vision of the Gospel."

- Verandering eis baie van leiers. McLaren (2000:219) wys uit dat nuwe lidmate in die kerk van die toekoms meesal postmodern sal wees terwyl die bestaande lidmatekorps hoofsaaklik modern sal wees. Sommige kerkleiers sal modern wees en ander postmodern. So 'n komplekse situasie sal besondere probleme en uitdagings tot gevolg hê, veral vir kerkleiers wat, volgens Sara Toth (in McLaren 2000:219) sal moet leer "to handle ambiguities, paradox ...[,] to embrace the fear of not knowing, in humble dependence upon the One who alone knows." Publieke teologie vra dat kerkleiers ondersteun word en dat daar vir hulle sorg gedra word. Die waarde wat hulle het vir die werk van die kerk in hierdie tyd behoort erken te word.

- Wat betref die postmoderne wêreld, is die uitdaging aan die kerk: verstaan dit, raak betrokke daarby, maak gereed vir verandering, leer om nuwe strategieë te ontwikkel vir altyd veranderende omstandighede. Elaine Graham (1996:50-51) stel 'n aantal sulke nuwe strategieë voor. Een strategie is ' $n$ verskuiwing van die pastor se fokus vanaf mense konfronteer op grond van 'n stel eksterne morele kodes (soos die standpunt van 'n gemeente in die Ring van Johannesburg van die Nederduitsch Hervormde Kerk by die 2006 Ringsvergadering dat ' $n$ vrou wat swanger geraak het en nie getroud is nie onder sensuur geplaas moet word - die pa van die kind is ook in die gemeente, maar oor hom is nie ' $n$ woord gerep nie) na mense begelei om moreel selfstandig te word. Een van die struikelblokke in die weg van so 'n verskuiwing is wat Graham (1996:50) noem "an impoverished vocabulary of moral discernment - in relation to the individual and the collective". James Poling (1995:122) wys daarop dat die pastorale taak van die kerk nog altyd was om te luister na en te sorg vir die wat in ly en in nood verkeer. Postmoderne uitdagings vir die pastorale aandag en sorg van die kerk is sake soos geregtigheid vir mense van albei geslagte, vir mense van alle rasse, vir die armes dwarsoor die wêreld. So 'n strategie vra volgens hom 'n hervorming van die modelle van pastorale sorg: 
The pastoral care movement has two choices. Either it is still a reform movement to change church and society, or it is a profession within the established patriarchal church and society concerned mainly with its own financial future, accreditation, and making sure it has a secure place for its members ... If our pastoral care movement decides to return to its earlier reformist goals, it must respond to the present crisis in the area of sexuality by focusing on issues of the liberation of women ... and gays and lesbians from the traditional sexual ethics that support male dominance.

(Poling 1995:122)

'n Lewe sonder spiritualiteit is om die sin van 'n mens se bestaan te soek in kulturele waardes (moderne of postmodern). 'n Egte Christelike identiteit kom nie van konformeer aan kultuurvoorskrifte nie. Die spiritualiteit inherent aan die evangelie is wees-met-Ander - 'n lewe waarin God teenwoordig word in die alledaagse bestaan.

\section{DIE WAARDE VAN PLURALITEIT VIR DIE EENHEID VAN DIE KERK}

Pluraliteit in die kerk kan positief gewaardeer word, maar behoort ook teologies duidelik begrens te word. Die grense lê volgens De Reuver (2004:305) op drie vlakke. Die eerste is die van die scopus daarvan. Die kerk is pneumaties van aard en op Christus gerig. Die Heilige Gees snoer almal wat God in Christus aanbid, saam tot 'n eenheid (kyk Hand 15:8, 28; 1 Kor 12:3, 13; Ef 3:16-19). Die tweede vlak is die van die doel van die pluriformiteit van die kerk. Dit is nie 'n doel in sigself nie. Die doel daarvan is die opbou van die liggaam van Christus. Verskeidenheid behoort by te dra tot die rykdom, diepte en reikwydte van die geloofsgemeenskap (kyk Ef 3:18-19). De Reuver (2004:305) verwoord dit soos volg: "Ecclesiologische pluraliteit is theologisch legitiem als zij de ene kerk dient." Die derde vlak waarop die begrensing van pluraliteit plaasvind in die geloofsgemeenskap is die habitus waar die pluraliteit uitgeleef word. Waar die habitus van die liefde vir Christus en vir ander ontbreek, verloor pluraliteit in die geloofsgemeenskap legitimiteit en het dit geen waarde meer nie (kyk 1 Kor 13; 16:22; Joh 4:20-21). Volgens De Reuver (2004:305) is liefde die grondhouding van waaruit die pluraliteit van die geloofsgemeenskap beleef kan word (kyk Deut 6:4-5; Mt 22:37; 1 Joh 4:911). Hierdie drie duidelike grense is nodig om die pluriforme geloofsgemeenskap te hou by God en by mekaar.

Mens-wees met ander en in teenwoordigheid van God kan die mense van hierdie era bevry van die leegheid waarmee moderne denke hulle gelaat 


\section{Postmoderne kerk-wees in die lig van publieke teologie}

het. Die self-vernietigende individualisme wat die erfenis is van 'n vroeër era, kan so oorstyg word. Ander, sy dit ander kerke of ander mense, kan aanvaar word met hulle andersheid. Andersheid hoef nie beleef te word as 'n bedreiging nie, maar kan daartoe bydra dat kerke hulle eie outentieke identiteit skep in egte verhoudings met ander (Burkhard 2004:250). Dan kan denominasies wegbeweeg van "kerkisme" en alle ander gelowiges aanvaar en liefhê as "kerk van Christus", as broers en susters in die geloof, as vriende van Jesus.

\section{Literatuurverwysings}

Ambler, R 1995. Where on earth is God? in Young, F (ed), Dare we speak of God in public? 90-99. Londen: Mowbray.

Anderson, $\mathrm{P}$ 1998. The origins of postmodernity. London: Verso.

Avis, P 2003. A church drawing near: Spirituality and mission in a post-Christian culture. London: T\&T Clark.

Buber, M 1958. I and Thou, tr by R G Smith. New York: Charles Scribner's Sons.

Burkhard, J J 2004. Apostolicity then and now: An ecumenical church in a postmodern world. Collegeville, MN: Liturgical Press. (Michael Glazier Books.)

Cobb, J B \& Griffin, D R 1976. Process Theology: An introductory exposition. Philadelphia, PA: Westminster.

Davis, C 1996. Levinas: An introduction. Notre Dame, IN: University of Notre Dame Press.

De Reuver, R 2004. Één kerk in meervoud: Een theologisch onderzoek naar de ecclesiologische waarde van pluraliteit. Zoetermeer: Boekencentrum. (IRTY Research Publication 3.)

Dillon, M C [1995] 1999. s v Derrida, Jacques. The Cambridge Dictionary of Philosophy.

Dingemans, G D J 1987. Een huis om in te wonen: Schetsen en bouwstenen voor een kerk en een kerkorde van de toekomst. 's Gravenhage: Boekencentrum. (Praktisch Theologische Handboeken 5.)

Dingemans, G D J 1988. Eenheid en verscheidenheid in de nieuwe SOW-kerk: Op zoek naar een nieuw paradigma, dat Hervormden en Gereformeerden kan inspireren om kerk te zijn in de geseculariseerde wereld van de een-entwintigste eeuw. Gereformeerd Theologisch Tijdschrift 88, 129-142.

Dingemans, G D J 1989. Pleidooi voor een open kerk, in Leidse lezingen. De kerk verbouwen: Dingemans' ecclesiologie critisch bekeken, 177-187. Nijkerk: Callenbach.

Dingemans, G D J [2000] 2001. De stem van de Roepende: Pneumatologie. 3e druk. Kampen: Kok.

Dingemans, G D J 2002. De diepte van de oppervlakte, in De Lange, F (red), Een aanlokkelijk geloof: De pneumatheologie van Dingemans doordacht, 124-147. Kampen: Kok. 
Farley, E 1987. Interpreting situations: An essay in Practical Theology, in Mudge, L \& Poling, J (eds), Formation and reflection: The promise of Practical Theology, 1-26. Philadelphia, PA: Fortress.

Graham, E L 1996. Transforming practice: Pastoral theology in an age of uncertainty. London: Mowbray.

Graham, L K 1997. Discovering images of God: Narratives of care among lesbians and gays. Louisville, KY: Westminster John Knox.

Guardino, T G 1989. Foundationalism and contemporary theology. Philosophy \& Theology 3, 241-252.

Guardino, T G 1990. Revelation and foundationalism: Toward hemeneutical and ontological appropriateness. Modern Theology 6, 221-235.

Guardino, T G 1995-1996. Philosophy within theology in light of the foundationalism debate. Philosophy \& Theology 9, 57-69.

Gutting, G [1995] 1999. s v Foucault, Michel. The Cambridge Dictionary of Philosophy.

Habermas, J 1981. Modernity versus postmodernity. New German Critique 22, 3-14.

Habermas, J 1987. The philosophical discourse of modernity: Twelve lectures, tr by $\mathrm{F}$ G Lawrence. Cambridge, MA: MIT Press.

Huber, W 1998. Kirche in der Zeitenwende: Gesellschaftlicher Wandel und Erneuerung der Kirche. Gütersloh: Bertelsmann Stiftung.

Hunt, S 2003. Alternative religions: A sociological introduction. Burlington, VT: Ashgate.

Hyman, G 2002. The predicament of postmodern theology: Radical orthodoxy or nihilist textualism? Louisville, KY: Westminster John Knox.

Janssen, J 2003. De jeugd, de religie en de toekomst: Een complexe verhouding. Praktische Theologie 30(1), 3-23.

Kearney, R 2001. The God who may be: A hermeneutics of religion. Bloomington, IN: Indiana University Press.

Lambourne, R A 1974. Religion, medicine and politics. Contact 44, 1-40.

Levinas, E [1961] 1969. Totality and infinity: An essay on exteriority, tr by A Lingis. Pittsburgh, PA: Duquesne University Press.

Levinas, E [1974] 1981. Otherwise than being, or beyond essence, tr by A Lingis. 's Gravenhage: Martinus Nijhoff.

Lyotard, J-F 1979. The postmodern condition: A report on knowledge, tr by $\mathrm{G}$ Bennington \& B Massumi. Minneapolis, MN: University of Minnesota Press.

Macmurray, J [1957a] 1966. The self as agent. Londen: Faber \& Faber.

Macmurray, J [1961b] 1966. Persons in relation. Londen: Faber \& Faber.

Martin, D 2005. On secularization: Towards a revised general theory . Burlington, VT: Ashgate.

McLaren, B D. [1998] 2000. The church on the other side: Doing ministry in the postmodern matrix. Revised and expanded edition of Reinventing your church. Grand Rapids, MI: Zondervan.

Mellert, R B 1976. What is Process Theology? New York: Paulist Press.

Miller, J B 1989. The emerging postmodern world, in Burnham, F B (ed), Postmodern Theology: Christian faith in a pluralistic world, 1-19 San Francisco, CA: HarperSanFrancisco.

Miller-McLemore, B J \& Gill-Austern, B L 1999. Feminist and womanist pastoral theology. Nashville, TN: Abingdon. 
Moser, P K [1995] 1999 s v "Foundationalism". The Cambridge Dictionary of Philosophy, 321-323.

Murphy, N 1990. Theology in the age of scientific reasoning. Ithaca, NY: Cornell University Press.

Murphy, N \& McClendon, J W 1988-1989. Distinguishing modern and postmodern theologies. Modern Theology 5, 191-214.

Newbigin, L 1983. The other side of 1984: Questions for the church. Londen/Genève: British Council of Churches/WCC.

Newbigin, L 1985. Unfinished agenda: An autobiography. Grand Rapids, MI: Eerdmans.

Newbigin, L 1991. Truth to tell: The gospel as public truth. Grand Rapids, MI: Eerdmans.

Newbigin, L 1994a. A word in season: Perspectives on Christian world missions. Grand Rapids, Ml: Eerdmans.

Newbigin, L [1989] 1994b. The gospel in a pluralist society. $5^{\mathrm{e}}$ druk. Grand Rapids, MI: Eerdmans.

Newbigin, L [1978] 1995. Proper confidence: Faith, doubt, and certainty in Christian discipleship. Grand Rapids, MI: Eerdmans.

Newbigin, L 1996. Truth and authority in modernity. Valley Forge, PA: Trinity.

Newbigin, L \& Weston P 2006. Lesslie Newbigin - missionary theologian: A reader. Paperback. Grand Rapids, MI: Eerdmans.

Osmer, R \& Schweitzer, F 2003. Religious education between modernization and globalization: New perspectives on the United States and Germany. Grand Rapids, MI: Eerdmans.

Oswald, R \& Leas, S 1987. The inviting church: A study of new member assimilation. New York: Alban Institute.

Palmer, P J 1981. The company of strangers: Christians and the renewal of America's public life. New York: Crossroad.

Peperzak, A T 1997. The philosophy of Emmanuel Levinas. Evanston, III: Northwestern University Press.

Regele, M 1995. Death of the church. Grand Rapids, MI: Zondervan.

Ricoeur, P 1992. Oneself as another, tr by K Blamey. Chicago, IL: University of Chigaco Press.

Runia, K 1989. De Heer nu is Geest, in Leidse lezingen: De kerk verbouwen: Dingemans' ecclesiologie critisch bekeken, 31-48. Nijkerk: Callenbach.

Sauter, G 1995. The question of meaning: A theological and philosophical orientation, ed and tr by G W Bromiley. Grand Rapids, MI: Eerdmans.

Schrag, C O [1995] 1999. s v "Pluralism". The Cambridge Dictionary of Philosophy.

Seeskin, K [1995] 1999. s v "Buber, Martin". The Cambridge Dictionary of Philosophy.

Stiver, D R 2001. Theology after Ricoeur: New directions in hermeneutical theology. Louisville, KY: Westminster John Knox.

Taylor, C 1989. The sources of the self: The making of the modern identity. Cambridge, Mass: Harvard University Press.

Taylor, C 1991. The ethics of authenticity. Cambridge, Mass: Harvard University Press.

Taylor, C 1999. A catholic modernity? Charles Taylor's Marianist Award Lecture, ed by J L Heft. New York: Oxford University Press. 
Thiel, J E 1994. Nonfoundationalism. Minneapolis, MN: Fortress.

Thornhill, J 2000. Modernity: Christianity's estranged child reconstructed. Grand Rapids, MI: Eerdmans.

Van der Ven, J A 1996. Ecclesiology in context. Grand Rapids, MI: Eerdmans.

Van Huyssteen, J W 1999. The shape of rationality: Toward interdisciplinarity in theology and science. Grand Rapids, MI: Eerdmans.

Volf, M 1996. Exclusion and embrace: A theological exploration of identity, otherness and reconciliation. Nashville, TN: Abingdon.

Weber, M [1947] 1968a. Max Weber: On charisma and institution building. Selected papers edited and with an introduction by E N Eisenstadt. Chicago, IL: University of Chicago Press.

Wellmer, A 1991. The persistence of modernity: Essays on aesthetics, ethics, and postmodernism, tr by D Midgley. Cambridge, Mass: MIT Press.

Wilson, M 1988. A coat of many colours: Pastoral studies of the Christian way of life. Londen: Epworth. 